Article

\title{
Oxidative Stress and Analysis of Selected SNPs of ACHE (rs 2571598), BCHE (rs 3495), CAT (rs 7943316), SIRT1 (rs 10823108), GSTP1 (rs 1695), and Gene GSTM1, GSTT1 in Chronic Organophosphates Exposed Groups from Cameroon and Pakistan
}

\author{
Leonel Javeres Mbah Ntepe ${ }^{1}\left(\mathbb{0}\right.$, Rabia Habib ${ }^{1, *}$, Ngondi Judith Laure ${ }^{2}$, Saqlain Raza ${ }^{3}$, \\ Eugenie Nepovimova ${ }^{4}$, Kamil Kuca ${ }^{4, *}$, Sajida Batool ${ }^{1}$, and Syed Muhammad Nurulain ${ }^{1, *(B)}$ \\ 1 Department of Biosciences, COMSATS University Islamabad, Chak Shahzad, Islamabad 45550, Pakistan; \\ mbahjl@yahoo.fr (L.J.M.N.); sajida.batool@comsats.edu.pk (S.B.) \\ 2 Department of Biochemistry, Yaoundé I University, Yaoundé 8024, Cameroon; ngondijudithl@hotmail.com \\ 3 Department of Mathematics, COMSATS University Islamabad, Chak Shahzad, Islamabad 45550, Pakistan; \\ saqlain.raza@comsats.edu.pk \\ 4 Department of Chemistry, Faculty of Science, University of Hradec Kralove, 50003 Hradec Kralove, \\ Czech Republic; eugenie.nepovimova@uhk.cz \\ * Correspondence: rabia.habib@comsats.edu.pk (R.H.); kamil.kuca@uhk.cz (K.K.); \\ syed.nurulain@comsats.edu.pk (S.M.N.)
}

Received: 12 August 2020; Accepted: 31 August 2020; Published: 3 September 2020

\begin{abstract}
The detrimental effects of organophosphates (OPs) on human health are thought to be of systemic, i.e., irreversible inhibition of acetylcholinesterase (AChE) at nerve synapses. However, several studies have shown that AChE inhibition alone cannot explain all the toxicological manifestations in prolonged exposure to OPs. The present study aimed to assess the status of antioxidants malondialdehyde (MDA), superoxide dismutase (SOD), glutathione (GSH) (reduced), catalase, and ferric reducing antioxidant power (FRAP) in chronic OP-exposed groups from Cameroon and Pakistan. Molecular analysis of genetic polymorphisms (SNPs) of glutathione transferases (GSTM1, GSTP1, GSTT1), catalase gene (CAT, rs7943316), sirtuin 1 gene (SIRT1, rs10823108), acetylcholinesterase gene ( $A C H E$, rs2571598), and butyrylcholinesterase gene ( $B C H E$, rs3495) were screened in the OP-exposed individuals to find the possible causative association with oxidative stress and toxicity. Cholinesterase and antioxidant activities were measured by colorimetric methods using a spectrophotometer. Salting-out method was employed for DNA extraction from blood followed by restriction fragment length polymorphism (RFLP) for molecular analysis. Cholinergic enzymes were significantly decreased in OP-exposed groups. Catalase and SOD were decreased and MDA and FRAP were increased in OP-exposed groups compared to unexposed groups in both groups. GSH was decreased only in Pakistani OPs-exposed group. Molecular analysis of ACHE, BCHE, Catalase, GSTP1, and GSTM1 SNPs revealed a tentative association with their phenotypic expression that is level of antioxidant and cholinergic enzymes. The study concludes that chronic OPs exposure induces oxidative stress which is associated with the related SNP polymorphism. The toxicogenetics of understudied SNPs were examined for the first time to our understanding. The findings may lead to a newer area of investigation on OPs induced health issues and toxicogenetics.
\end{abstract}

Keywords: organophosphates; antioxidants; cholinergic enzymes; SNPs; toxicogenetics 


\section{Introduction}

Pesticides are an important class of environmental chemical pollutants. Their steady and continuous use for more than half a century has now become a major public health problem, killing at least 250,000-370,000 people every year [1]. Pesticides exposure is one of the notable contributors to morbidity particularly in the developing part of the world [2]. Epidemiological studies have found that pesticide exposure may result in metabolic disorders, infertility, neurological problems, or weak immune system. Insecticides have also been linked to human DNA damage, multiple degenerative diseases, and cancer [3-5]. Organophosphates (OPs) are one of the widely used pesticides (more than $50 \%$ of world consumption) globally and their use is expected to increase even more in coming years, with the direct consequence of increased health problems [6,7]. Adverse health effects of OPs have been attributed predominantly to their systemic actions, i.e., they block the degradation of acetylcholine at cholinergic synapses by irreversible inhibition of acetylcholinesterase (AChE) and butyrylcholinesterase (BChE) $[8,9]$. However, several studies have revealed that inhibition of cholinesterase alone is insufficient to explain the varied range of disorders reported after OPs exposure [10-12]. Consequently, a search of other associated mechanisms to explain the toxicity of OPs was deemed necessary. Several toxicological and epidemiological studies thus far have shown that OPs can induce oxidative stress (OS) by increasing reactive oxygen species (ROS) and reactive nitrogen species (RNS). These reactive oxygen and nitrogen intermediates can react with biological macromolecules altering their physiological functions [13-15]. For instance, the free radicals (FR) can induce depolarization of the mitochondrial membrane, accompanied by generation of ROS and release of numerous pro-apoptotic proteins, such as cytochrome C, which can lead to cell death by apoptosis [16-18]. FR can also cause genotoxicity by lipid peroxidation which leads to chromosomal breaks, single-stranded DNA breaks with serious consequences on replication or transmission of a genetic message and proteins synthesis $[19,20]$.

Antioxidant enzymes like the superoxide dismutase (SOD), glutathione peroxidase, malondialdehyde (MDA), catalase (CAT), and glutathione (GSH) act as endogenous free-radical scavengers to limit the damage caused by OS. However, pesticides can interfere with these enzymatic activities damaging antioxidant defenses, thus affecting their ability to fight oxidative stress. Many studies have explored the relationship between pesticide exposure and OPs with varying and controversial results. Those studies have assessed various tissues and blood at diverse doses and exposure surroundings (either acute or chronic). Prakasam et al. and Rastogi et al. [21,22] show a marked surge in MDA in those exposed to organophosphate pesticides. The rise in CAT and SOD have also been described by different studies [23-25]. On the other hand, Lu et al. [26], showed a decrease in SOD, CAT, and GSH in OP-exposed individuals. Ahmad et al. [27] showed that GST protects lungs and brain from toxic effects of pesticides. One major challenge in work-related pesticide exposure exploration stems from the unevenness in individual reactions and genetic susceptibilities, and variances in sensibilities to a particular chemical. Genetic polymorphisms (SNPs) of the pesticide-metabolizing enzymes may also affect the toxicity of pesticides and boost or reduce the sensitivity to some of the compounds. It has been reported that subjects with null genotypes for GSTM1 and GSTT1 are more pesticides susceptible [28]. These reports clearly indicate that oxidative stress and associated SNPs have an influence in the pathogenesis-related to OPs pesticide toxicity. However, only few studies have investigated the effects of chronic OPs exposure on human health so far.

This study was therefore undertaken to establish if continued low-level exposure to mixtures of organophosphorus pesticides could result in alterations in antioxidants and cholinergic enzymes. In addition, impact of SNPs of some antioxidants and cholinergic enzymes; glutathione transferases (GSTM1, GSTP1, GSTT1), CAT (rs7943316), ACHE (rs2571598), BCHE (rs3495), and SIRT1 (rs10823108) has been evaluated for the first time to our understanding. The study mainly evaluated the interactions between OPs exposure and genetic polymorphisms and their impact on antioxidants enzymes activities. Only a few studies have been conducted on gene-environment interactions in populations exposed to organophosphorus pesticides in general and no such data is available for Central Africa. Beyond the process of early diagnosis, prevention and non-OP-exposed of diseases associated with long-term 
exposure to Ops. Our study will provide the crucial evidence on the need for individualized health interventions or pharmaco-genetics based therapeutic approaches.

\section{Result}

\subsection{Sociodemographic and Clinical Profile of Subjects Exposed to Ops}

The distribution of the population according to socio-demographic characteristics (Table 1) shows that majority of exposed Pakistanis and Cameroonians were between 16 and 30 years old. Sex ratio (Male/Female) was 2.85 in the Pakistani group against 1.00 in the Cameroonian group. $44.5 \%$ of Pakistani population were overweight (BMI $\geq 25$ ), $25 \%$ were obese, $56 \%$ had high systolic blood pressure (B.P.), and 56.5\% had high diastolic blood pressure. In the exposed population of Cameroon, $45.5 \%$ were overweight, $34 \%$ were obese, $58.5 \%$ had high systolic, and $66 \%$ had high diastolic blood pressure.

Table 1. Sociodemographic characteristics of study participants.

\begin{tabular}{|c|c|c|c|c|c|c|}
\hline \multirow{2}{*}{ Groups } & \multicolumn{3}{|c|}{ Cameroon } & \multicolumn{3}{|c|}{ Pakistan } \\
\hline & $\begin{array}{c}\text { Unexposed } \\
n(\%)\end{array}$ & $\begin{array}{l}\text { Exposed } n \\
\quad(\%)\end{array}$ & $p$-Value & $\begin{array}{c}\text { Unexposed } \\
n(\%)\end{array}$ & $\begin{array}{l}\text { Exposed } n \\
\quad(\%)\end{array}$ & $p$-Value \\
\hline \multicolumn{7}{|c|}{ Age-frequency } \\
\hline $16-30$ & $80(64)$ & $109(54.5)$ & 0.158 & 38 (33.9) & $115(57.5)$ & 0.146 \\
\hline $31-45$ & $25(20)$ & $71(35.5)$ & & $49(43.8)$ & $60(30)$ & \\
\hline $46-61$ & $20(16)$ & $20(10)$ & & $25(22.3)$ & $25(12.5)$ & \\
\hline \multicolumn{7}{|c|}{ Gender-frequency } \\
\hline Female & $63(50.4)$ & $100(50)$ & 0.602 & $46(41.1)$ & $52(26)$ & $<0.05$ \\
\hline Male & $62(49.6)$ & $100(50)$ & & $66(58.9)$ & $148(74)$ & \\
\hline \multicolumn{7}{|c|}{ BMI-frequency } \\
\hline Underweight & $8(6.4)$ & $9(4.5)$ & $<0.001$ & $4(3.6)$ & $11(5.5)$ & $<0.001$ \\
\hline Normal range & $81(64.8)$ & $32(16)$ & & $63(56.2)$ & $50(25)$ & \\
\hline Overweight & $13(10.4)$ & $91(45.5)$ & & $38(33.9)$ & $89(44.5)$ & \\
\hline Obese & $23(18.4)$ & $68(34)$ & & $7(6.2)$ & $50(25)$ & \\
\hline \multicolumn{7}{|c|}{ SBP-frequency } \\
\hline Hypotension & $15(12)$ & $3(1.5)$ & $<0.001$ & $8(7.1)$ & $11(5.5)$ & $<0.001$ \\
\hline Normal range & $90(72)$ & $80(40)$ & & $88(78.6)$ & $77(38.5)$ & \\
\hline Hypertension & $20(16)$ & $117(58.5)$ & & $16(14.3)$ & $112(56)$ & \\
\hline \multicolumn{7}{|c|}{ DBP-frequency } \\
\hline Hypotension & $9(7.2)$ & $8(4)$ & $<0.001$ & $9(8.0)$ & $15(7.5)$ & $<0.001$ \\
\hline Normal range & $86(68.8)$ & $60(30)$ & & $91(81.2)$ & $72(36)$ & \\
\hline Hypertension & $30(24)$ & $132(66)$ & & $12(10.7)$ & $113(56.5)$ & \\
\hline
\end{tabular}

$n=$ number of patients, $\mathrm{SBP}=$ systolic blood pressure, $\mathrm{DBP}=$ diastolic blood pressure, $\mathrm{BMI}=$ Body mass index.

\subsection{Pesticide Exposure and Effects on Oxidative Stress}

Cholinergic enzyme activities are shown in Table 2. $44.42 \%$ Pakistani and $42.86 \%$ RBC-AChE in Cameroonians exposed individuals were depressed in comparison to non-exposed non-OP-exposed group. Reduction in activity is statistically significant. BChE activity was also decreased (Table 2) and statistically significant $(p<0.05)$.

Table 2. Status of cholinergic enzymes in unexposed and OP-exposed groups.

\begin{tabular}{ccccc}
\hline \multirow{2}{*}{ Groups } & \multicolumn{2}{c}{ Cameroon } & \multicolumn{2}{c}{ Pakistan } \\
& $\begin{array}{c}\text { Unexposed }(n= \\
\text { 125) Mean } \pm \text { SD }\end{array}$ & $\begin{array}{c}\text { 200) Mean } \pm \text { SD } \\
\end{array}$ & $\begin{array}{c}\text { 112) Mean } \pm \text { SD } \\
\text { 200) Mean } \pm \text { SD }\end{array}$ \\
\hline $\mathrm{AChE} \mathrm{mU} / \mu \mathrm{mol} \mathrm{Hb}$ & $0.21 \pm 0.09^{\mathrm{c}}$ & $0.12 \pm 0.05^{*, \mathrm{a}}$ & $0.33 \pm 0.07^{\mathrm{d}}$ & $0.19 \pm 0.06^{*, \mathrm{~b}}$ \\
$\mathrm{BChE} \mu \mathrm{mol} / \mathrm{l} / \mathrm{min}$ & $0.021 \pm 0.009^{\mathrm{b}, \mathrm{c}}$ & $0.019 \pm 0.010^{*, \mathrm{a}}$ & $0.032 \pm 0.006^{\mathrm{c}}$ & $0.022 \pm 0.009^{*, \mathrm{~b}}$ \\
\hline
\end{tabular}

$\mathrm{SD}=$ Standard deviation, ${ }^{*} p \leq 0.05 ;{ }^{\mathrm{a}, \mathrm{b}, \mathrm{c}, \mathrm{d}}=$ Significance degree for Tukey Post-hoc test (Anova-one way). 
OPs residues determination by GC-MS (Figure 1) revealed the presence of three Ops: malathion, (Mean \pm SD: $200.12 \mathrm{ng} / \mathrm{mL} \pm 25.14$ ), parathion (Mean \pm SD: $297.27 \mathrm{ng} / \mathrm{mL} \pm 40.29$ ), and chlorpyrifos (Mean \pm SD: $0.37 \mathrm{ng} / \mathrm{mL} \pm 0.09$ ) in the Cameroonian OP-exposed group. No parathion residue was found in the Pakistani OP-exposed group in our detection range. Malathion was ( $57.97 \mathrm{ng} / \mathrm{mL} \pm 12.73$ ) and chlorpyrifos was found to be $(0.97 \mathrm{ng} / \mathrm{mL} \pm 0.07)$ present in Pakistani group. For antioxidant enzymes (Table 3), a reduction in catalase, SOD, GSH (reduced), and rise in MDA and FRAP were observed in exposed subjects which were significant $(p \leq 0.05)$ except GSH in Cameroonian population.

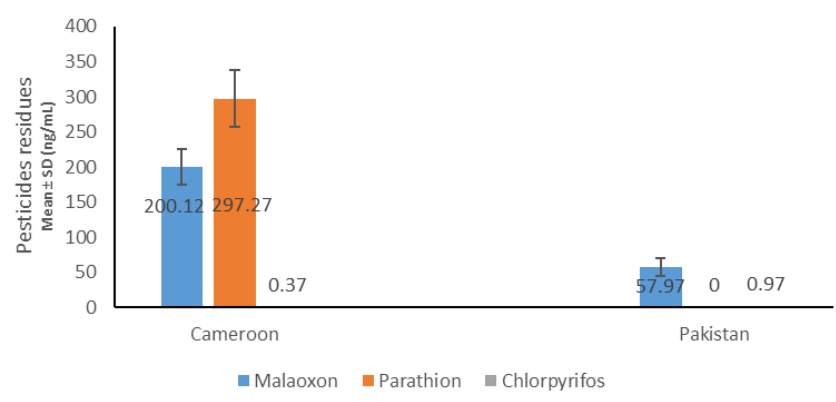

Figure 1. Blood pesticides levels in Cameroonian and Pakistani groups.

Table 3. Status of antioxidant enzymes in unexposed and OP-exposed groups.

\begin{tabular}{|c|c|c|c|c|}
\hline \multirow{2}{*}{ Groups } & \multicolumn{2}{|c|}{ Cameroon } & \multicolumn{2}{|c|}{ Pakistan } \\
\hline & $\begin{array}{l}\text { Unexposed ( } n= \\
\text { 125) Mean } \pm \text { SD }\end{array}$ & $\begin{array}{l}\text { Exposed }(n=200) \\
\text { Mean } \pm \text { SD }\end{array}$ & $\begin{array}{l}\text { Unexposed }(n= \\
\text { 112) Mean } \pm \text { SD }\end{array}$ & $\begin{array}{c}\text { Exposed }(n=200) \\
\text { Mean } \pm \text { SD }\end{array}$ \\
\hline $\begin{array}{l}\text { Catalase U/mg } \\
\text { protein }\end{array}$ & $0.714 \pm 0.607^{\mathrm{d}}$ & $0.301 \pm 0.201 *, \mathrm{~b}$ & $0.513 \pm 0.240^{c}$ & $0.223 \pm 0.110 *, \mathrm{a}$ \\
\hline SOD U/mg protein & $51.88 \pm 32.78^{b}$ & $41.07 \pm 13.09 *$, a & $42.62 \pm 19.35^{\mathrm{a}, \mathrm{b}}$ & $33.54 \pm 16.33 *, \mathrm{a}$ \\
\hline $\begin{array}{c}\text { MDA nmol } \\
\text { MDA/mg protein }\end{array}$ & $0.89 \pm 0.41^{\mathrm{a}}$ & $1.95 \pm 0.85 * \mathrm{c}$ & $0.99 \pm 0.31^{\mathrm{a}}$ & $1.22 \pm 0.37 *, b$ \\
\hline $\mathrm{GSH} \mu \mathrm{g} / \mathrm{mL}$ & $21.81 \pm 4.43^{\mathrm{a}}$ & $21.26 \pm 6.61^{a}$ & $29.55 \pm 5.18^{b}$ & $21.77 \pm 4.10^{*, \mathrm{a}}$ \\
\hline FRAP $\mu \mathrm{M}$ & $122.31 \pm 104.85^{a}$ & $419.50 \pm 238.81 * \mathrm{~d}$ & $252.54 \pm 56.07^{b}$ & $351.65 \pm 97.70 *, \mathrm{c}$ \\
\hline
\end{tabular}

\subsection{Genetic Association Analysis}

Allele and genotype frequencies results of all SNPs are summarized in Table 4. For GSTP1 rs1695, statistically significant differenes was noted in the genotypes frequencies in Cameroonian OP-exposed groups compared to healthy controls. Out of 200 exposed subjects, $42 \%$ were homozygous for the major allele, $37.5 \%$ were heterozygous GA, while $20.5 \%$ were homozygous for G minor allele. Significant association of GSTP1 rs1695 SNP with effects of OPs exposure in Cameroonian OP-exposed individuals was detected in DM and allelic models.

Variation in glutathione level according to genotypes (Figure 2A) showed statistical signficant differences between genotypes and serum GSH levels in the Pakistani exposed subjects compared to the non-OP-exposed subjects, but the result was not significant in the Cameroon exposed groups.

Difference in allele and genotype frequencies of CAT rs7943316 among exposed subjects and non-OP-exposed of both countries were statistically significant. Significant association of CAT with risk of OPs toxicity was revealed in Pakistani (DM: OR $=0.394$, allele) and in Cameroonian ( $\mathrm{OR}=0.422$ for DM, only) exposed group (Table 4). There are significant differences in catalase levels according to CAT SNP genotypes in OP-exposed subjects compared to non-OP-exposed in the Pakistani and Cameroonian populations (Figure 2B).

In the case of BCHE (SNP rs3495), significant association of BCHE risk allele with susceptibility to OPs toxicity was obseved in Pakistani OP-exposed subjects in all inhertance models (Table 4), while significant association was noted in DM and allelic modals for Cameroonian exposed subjects (Table 4). 
Table 4. Genotypes and Alleles frequencies in unexposed and OP-exposed groups.

\begin{tabular}{|c|c|c|c|c|c|c|c|c|c|}
\hline \multicolumn{2}{|c|}{ Genotype } & \multicolumn{4}{|c|}{ Cameroon } & \multicolumn{4}{|c|}{ Pakistan } \\
\hline \multirow{7}{*}{ GSTP1 } & AA & $70(56)$ & $84(42)$ & & \multirow{3}{*}{$6.167(0.045)$} & $34(30.36)$ & $47(23.5 \%)$ & \multirow{5}{*}{$\begin{array}{c}0.704 \\
(0.419-1.184) \\
1.050 \\
(0.582-1.893)\end{array}$} & \multirow{3}{*}{$1.810(0.404)$} \\
\hline & AG & $34(27.2)$ & $75(37.5)$ & & & $57(50.89)$ & $114(57)$ & & \\
\hline & GG & $21(16.8)$ & $41(20.5)$ & & & $21(18.75)$ & $39(19.5)$ & & \\
\hline & $\begin{array}{c}\text { DM AG + GG } \\
\text { vs. AA }\end{array}$ & & & \multicolumn{2}{|c|}{$0.569(0.362-0.893) 6.047(0.013)$} & & & & $1.756(0.185)$ \\
\hline & $\begin{array}{c}\mathrm{RM} A G+\mathrm{AA} \\
\text { vs. GG }\end{array}$ & & & $\begin{array}{c}1.240 \\
(0.692-2.220)\end{array}$ & $0.526(0.468)$ & & & & $0.026(0.871)$ \\
\hline & A & $174(69.6)$ & $242(60.5)$ & 0.666 & \multirow[b]{2}{*}{$5.641(0.017)$} & $125(55.80)$ & $208(52)$ & 0.858 & \multirow{2}{*}{$0.834(0.360)$} \\
\hline & G & $76(30.4)$ & 158 (39.5) & $(0.476-0.932)$ & & $99(44.20$ & $192(48)$ & $(0.617-1.192)$ & \\
\hline \multirow{7}{*}{ CAT } & AA & $68(54.4)$ & $67(33.5)$ & & \multirow{3}{*}{$14.05(0.009)$} & $67(59.82)$ & $74(37)$ & & \multirow{3}{*}{$15.80(0.001)$} \\
\hline & AT & $48(38.4$ & $115(57.5)$ & & & $30(26.78)$ & $93(46.5)$ & & \\
\hline & TT & $9(7.2)$ & $18(9)$ & & & 15 (13.40) & $33(16.5)$ & & \\
\hline & $\begin{array}{c}\mathrm{DM} \text { AT + TT } \\
\text { vs. AA }\end{array}$ & & & $\begin{array}{c}0.422 \\
(0.267-0.667)\end{array}$ & $13.84(0.002)$ & & & $\begin{array}{c}0.394 \\
(0.245-0.634)\end{array}$ & $15.10(0.001)$ \\
\hline & $\mathrm{RM} \mathrm{AT}+\mathrm{AA}$ & & & $\begin{array}{c}1.275 \\
(0.553-2934)\end{array}$ & $0.327(0.567)$ & & & $\begin{array}{c}1.278 \\
(060-2472)\end{array}$ & (0.532) 0.465 \\
\hline & A & $184(73.6)$ & $249(62.25)$ & 0.554 & \multirow{2}{*}{$8.912(0.002)$} & $164(73.21)$ & $241(60.25)$ & 0.591 & \multirow{2}{*}{$10.59(0.001)$} \\
\hline & $\mathrm{T}$ & $66(26.4)$ & $151(37.75)$ & $(0.388-0.792)$ & & $60(26.79)$ & $159(39.5)$ & $(0.418-0.836)$ & \\
\hline \multirow{8}{*}{ BCHE } & GG & $26(20.8)$ & $33(16.5)$ & & \multirow{3}{*}{$34.97(0.000)$} & $56(50)$ & $70(35)$ & & \multirow{3}{*}{$8.695(0.01)$} \\
\hline & GA & $70(56)$ & $56(28)$ & & & $35(31.25)$ & $66(33)$ & & \\
\hline & $\mathrm{AA}$ & $29(23.2)$ & $111(55.5)$ & & & $21(18.75)$ & $64(32)$ & & \\
\hline & $\begin{array}{c}\mathrm{DM} \text { GA + AA } \\
\text { vs. GG }\end{array}$ & & & $\begin{array}{c}1.329 \\
(0.750-2353)\end{array}$ & $0.957(0.327)$ & & & $\begin{array}{c}1.857 \\
(160-2974)\end{array}$ & $6.710(0.01)$ \\
\hline & RM GA + GG & & & 0.247 & \multirow{2}{*}{$31.61(0.000)$} & & & 0.490 & \multirow{2}{*}{$12.73(0.001)$} \\
\hline & vs. AA & & & $(0.149-0.408)$ & & & & $(1.979-16.58)$ & \\
\hline & G & $122(48.8)$ & $122(30.5)$ & 0.460 & \multirow{2}{*}{21.970 .000} & 147 (65.63) & $206(51.5)$ & 0.556 & \multirow{2}{*}{$6.359(0.01)$} \\
\hline & A & $128(51.2)$ & $278(69.5)$ & $(0.332-0.638)$ & & 77 (34.37) & $194(48.4)$ & $(0.280-0.858)$ & \\
\hline
\end{tabular}


Table 4. Cont

\begin{tabular}{|c|c|c|c|c|c|c|c|c|c|}
\hline \multirow{7}{*}{$A C H E$} & GG & $85(68)$ & 110 (55) & & \multirow{3}{*}{$9.843(0.007)$} & 70 (62.5) & $78(39)$ & & \multirow{3}{*}{$21.14(0.001)$} \\
\hline & GT & $23(18.4)$ & $69(34.5)$ & & & $38(33.93)$ & 87 (43.5) & & \\
\hline & TT & 17 (13.6) & $21(10.5)$ & & & $4(3.57)$ & 35 (17.5) & & \\
\hline & $\begin{array}{c}\text { DM GT + TT } \\
\text { vs. GG }\end{array}$ & & & $\begin{array}{c}0.575 \\
(0.360-0.918)\end{array}$ & 5.417 (0.019) & & & $\begin{array}{c}0.383 \\
(0.238-0.617)\end{array}$ & $15.90(0.001)$ \\
\hline & $\begin{array}{c}\text { RM GT + GG } \\
\text { vs. TT }\end{array}$ & & & $\begin{array}{c}0.745 \\
(0.376-1.475)\end{array}$ & $0.715(0.397)$ & & & $\begin{array}{c}5.72 \\
(1.979-16.58)\end{array}$ & $12.73(0.001)$ \\
\hline & G & 193 (77.2) & $289(72.25)$ & 0.768 & \multirow{2}{*}{1.9670 .160} & $178(79.46)$ & $243(60.75)$ & 0.400 & \multirow{2}{*}{$22.91(0.001)$} \\
\hline & $\mathrm{T}$ & $57(22.8)$ & $111(27.75)$ & $(0.532-1.111)$ & & $46(20.54)$ & $157(39.25)$ & $(0.273-0.585)$ & \\
\hline \multirow{7}{*}{ SIRT1 } & GG & $28(22.4)$ & 39 (19.5) & & \multirow{3}{*}{$2.5(0.286)$} & 45 (40.18) & $81(40.5)$ & & \multirow{3}{*}{$0.23(0.891)$} \\
\hline & GA & $82(65.6)$ & $124(62)$ & & & 44 (39.29) & $74(37)$ & & \\
\hline & AA & $15(12)$ & 37 (18.5) & & & $23(20.53)$ & $45(22.5)$ & & \\
\hline & $\begin{array}{c}\text { DM GA + } \\
\text { AA.Vs GG }\end{array}$ & & & $\begin{array}{c}0.839 \\
(0.485-1.45)\end{array}$ & $0.395(0.529)$ & & & $\begin{array}{c}1.013 \\
0.632-1.624\end{array}$ & $0.003(0.957)$ \\
\hline & $\begin{array}{c}\text { RM GA + GG } \\
\text { vs. AA }\end{array}$ & & & $\begin{array}{c}1.665 \\
(0.871-3.179)\end{array}$ & $2.41(0.119)$ & & & $\begin{array}{c}1.123 \\
(0.637-1.979)\end{array}$ & $0.162(0.686)$ \\
\hline & G & $138(55.2)$ & $202(50.5)$ & 0.828 & \multirow{2}{*}{$1.362(0.243)$} & $134(59.82)$ & $236(59)$ & 0.966 & \multirow{2}{*}{$0.040(0.841)$} \\
\hline & A & $112(44.8)$ & $198(49.5)$ & $(0.602-1.137)$ & & $90(40.18)$ & $164(41)$ & $(0.692-1.349)$ & \\
\hline \multirow{2}{*}{ GSTM1 } & Present (+) & $106(84.8)$ & $143(71.5)$ & 0.449 & \multirow{2}{*}{$7.595(0.005)$} & $96(85.71$ & $175(87.5)$ & 1.167 & \multirow{2}{*}{$0.200(0.654)$} \\
\hline & Absent (-) & 19 (15.2) & $57(28.5)$ & $(0.252-0.800)$ & & $16(14.29)$ & 25 (12.5) & $(0.593-2.29) 2$ & \\
\hline \multirow{2}{*}{ GSTT1 } & Present $(+)$ & $108(86.4)$ & $149(74.5)$ & 0.459 & \multirow{2}{*}{6.5840 .010} & $94(83.93)$ & $172(86)$ & 1.176 & \multirow{2}{*}{$0.245(0.620)$} \\
\hline & Absent (-) & 17 (13.6) & $51(25.5)$ & $(0.251-0.839)$ & & $18(16.07)$ & $28(14)$ & $(0.618-2.239)$ & \\
\hline
\end{tabular}



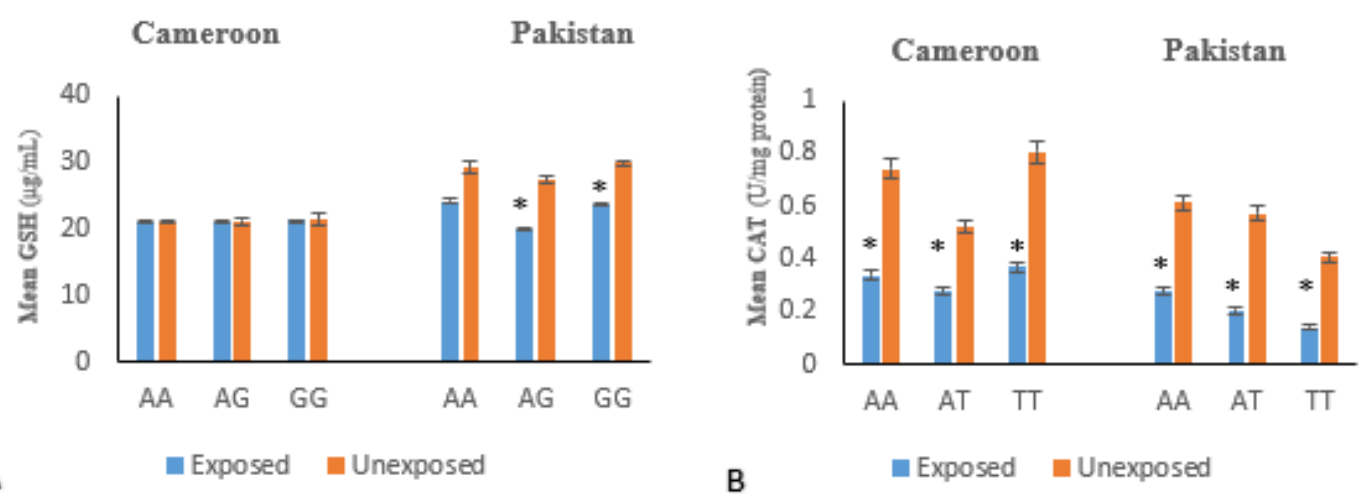

A
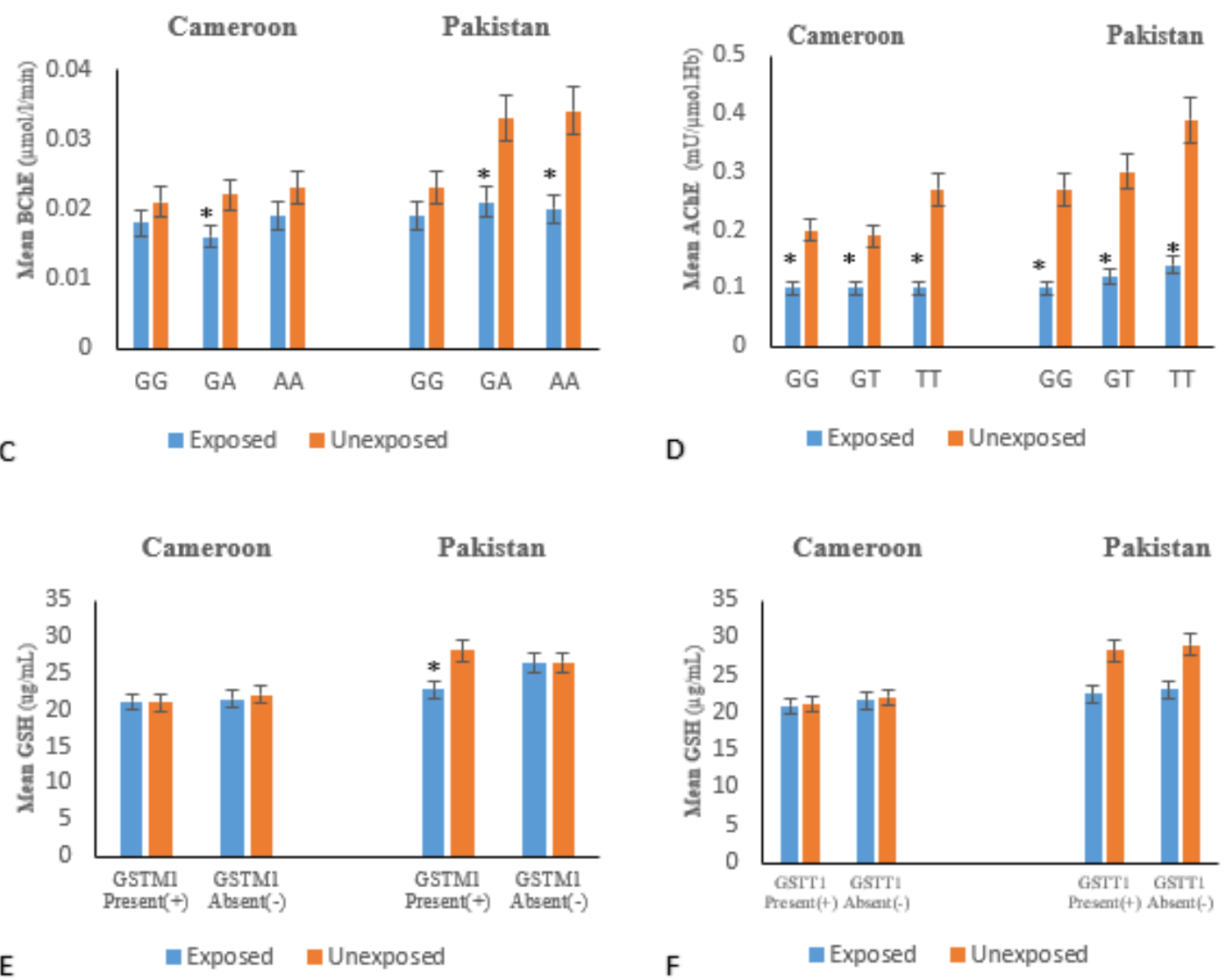

Figure 2. Variation of biochemical parameters according to different genotype: The results were significant if * $p \leq 0.05$. (A) GSTP1 gene; (B) CAT gene; (C) BChE gene; (D) ACHE gene; (E) GSTM1 gene; and (F) GSTT1 gene.

Regarding AChE SNP rs2571598 allele and genotype frequencies between exposed subjects and non-OP-exposed were significantly different in Pakistani population. On the other hand, only genotypic frequencies' differences were statistically significant in the Cameroonian population (Table 4). A significant association between ACHE SNP rs2571598 and susceptibility to OPs toxicity was identified in Pakistani exposed subjects in all inheritance models, whereas in Cameroonian exposed group significant association was noted only in DM inhertance model (Table 4).

SIRT1(rs10823108) revealed no substantial differences in allele frequencies and genotypes between OP-exposed and non exposed in both countries. Consequently, no association between these SNPs and risk to OPs exposure toxicity has been identified among Pakistanis and Cameroonians. Comparison of OP-exposed and non exposed with GSTT1 and GSTM1 null loci (Table 3) showed statistically significant 
differences only in the Cameroonian population ( $\mathrm{OR}=0.449$ and $95 \% \mathrm{CI}=0.252-0.800$ for GSTM1; $\mathrm{OR}=0.459$ and $\mathrm{CI}=0.251-0.839$ for GSTT1).

Logistic regression analysis of different gene SNPs (rs1695, rs7943316, rs3495, and 2571598) in dominant model according to studied biochemical parameters (Figure 3A-H) showed statistically significant differences for cholinergic enzymes (AChE and BChE) and antioxidant enzymes (CAT, SOD, and MDA) in OPs-exposed individuals of both countries. ACHE SNPs rs 2571598 was positively associated with BMI ( $p=0.04 ; \mathrm{OR}=0.92 ; \mathrm{CI}=0.74-1.91$ ) in Pakistani population (Figure 3G). It was also associated with FRAP levels $(p=0.04 ; \mathrm{OR}=1.30 ; \mathrm{CI}=0.96-1.58)$ in the Cameroonian population (Figure $3 \mathrm{H}$ ).

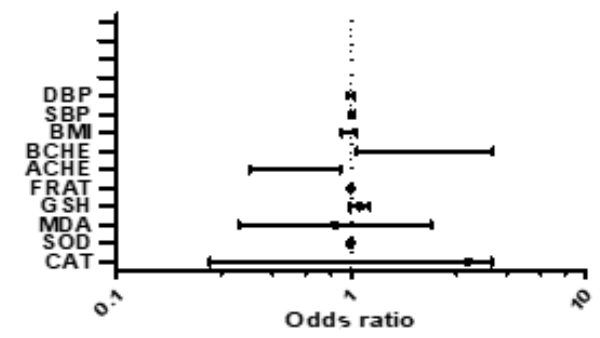

A
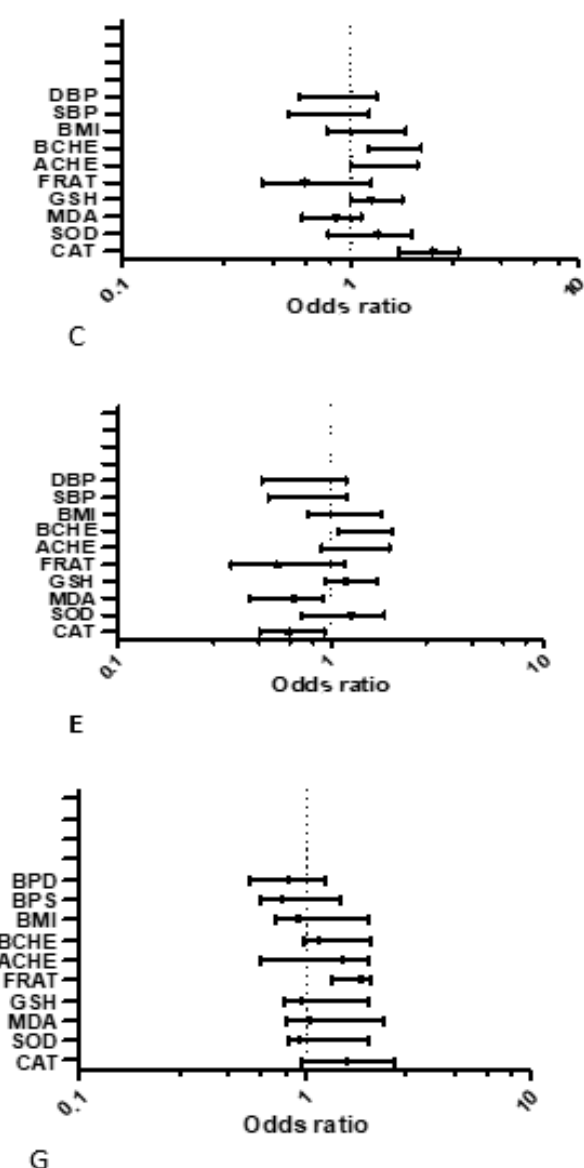

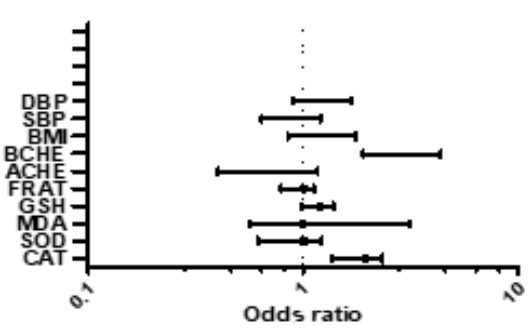

B
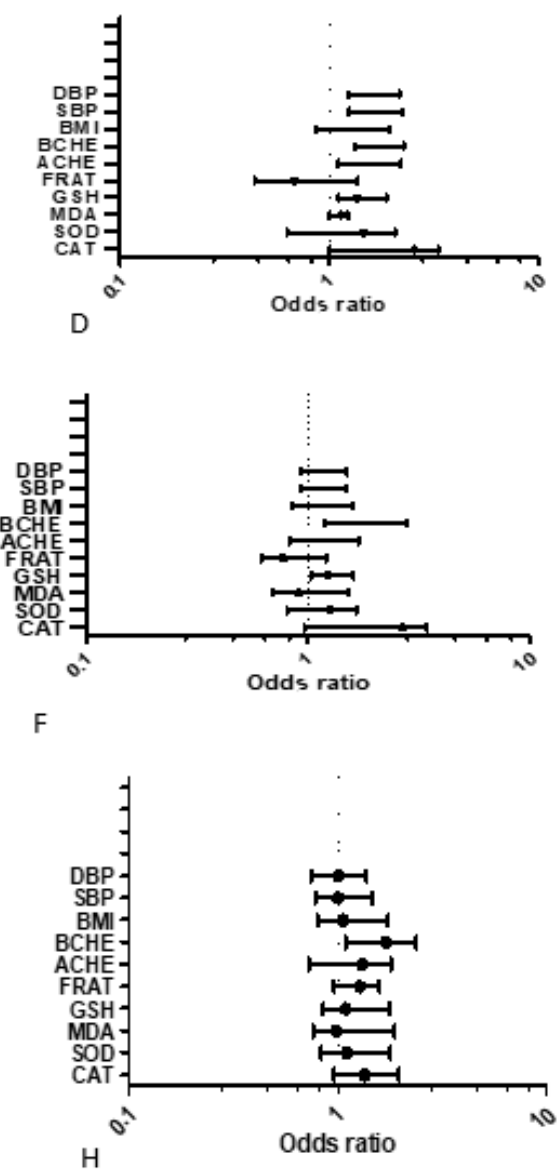

Figure 3. Multiple Logistic regression (MLR) analysis of genetic polymorphisms (SNPs) in dominant model according to Biochemical Variables of OPs-exposed population: The model was adjusted for each SNPs (0: major homozygote; 1: heterozygote + minor homozygote). The results were significant if $p \leq$ 0.05. (A) MLR for GSTP1 gene of Pakistan; (B) MLR for GSTP1 gene of Cameroon; (C) MLR for catalase gene of Pakistan; (D) MLR for gene of exposed Cameroon; (E) MLR for BCHE gene of Pakistan; (F) MLR for BCHE gene of Cameroon; (G) MLR for ACHE gene of Pakistan; and (H) MLR for ACHE gene of Cameroon. 


\section{Discussion}

Organophosphorus compounds makeup about $80 \%$ of the total insecticides/pesticides consumption across the world. Globally, thousands of peoples die each year due to pesticide poisoning [1]. Intoxication and maladies due to acute and chronic exposure in populations is regularly reported in literature [29-33]. Mixture of OPs even at low non-lethal dose may pose enhanced threat because of the possibility of synergistic effect between two OPs [34,35]. Reduction of AChE activity is an essential biological marker for OPs exposure [6,36,37]. A significant decrease in cholinergic enzymes (AChE and $\mathrm{BChE}$ ) in OP-exposed groups were noted (Table 2) in the study, indicating the OPs exposure in research participants. The OPs exposure was further confirmed by presence of empty pesticides containers in the area, in addition to the verbal inquiry from pesticides applicator in the region. Blood pesticides residues were determined in the plasma which showed the presence of three types of OPs (malathion, parathion, and chlorpyrifos) in theOP-exposed groups (Figure 1).

Our results indicate that chronic exposure of OPs pesticides can lead to an imbalance in antioxidant enzymes. Oxidative stress has been reported as one of the toxic manifestation of organophoshates and a co-morbidity and mortality factor in OP poisoning [8]. However, controversialresults also exists which is attributed to the structurally and functionally diversified organophosphates [8]. However, reports are mainly based on in vitro and animal models studies on organ toxicity. [38-41]. Secondly, most of the studies were related with mild toxic OPs like malathion [42,43], whereas extremely toxic OP, for instance, paraoxon or mixtures of Ops, may exhibit different toxicological profiles, although they have a common mechanism of poisoning that is inhibition of AChE [10,11]. In the present study, a mixture of OPs malathion+chlorpyrifos+/parathion) residues were found in chronically exposed subjects and exhibited enzymatic anti-oxidants irregularities. Damage made by oxidative stress mainly happens through the production of ROS [44] and one of the ROS deactivating pathways is mediated by catalase.

A significantly lower activity of CAT and SOD levels in OP-exposed peoples compared to non-OP-exposed subjects was observed in both populations groups. GSH was found to be decreased only in Pakistani exposed group. A decrease in activity of these enzymes would favor the accumulation of free oxygen radicals in erythrocytes and other cells, leading to tissue damage which could be significantly detrimental when pesticides exposure persists over several years and may ultimately be responsible for multipletissue and organ damages (neurological, metabolic, hepatic, and renal) [45-47]. We also observed an increase in MDA and FRAP in OP-exposed individuals. A higher level of MDA and FRAP, could suggest an increase in lipid peroxidation in exposed individuals. Our observation is consistent with previous studies where a reduction in AChE activity was correlated with a decrease in antioxidant enzymes and an increase in lipid peroxidation after sub-chronic and chronic OPs exposure [48,49].

It is evident from the literature thatpresence of certain SNPs in detoxyfying/antioxidant pathway genes helps in predicting the individual's susceptibility to pesticide induced toxicity. [50,51]. Moreover, genotypes determine the modulations of proteins and enzymes involved in DNA metabolism, detoxification, and repair systems, influencing heterogeneity of responses to pesticides and their metabolism [52]. SNPs analysis on selected cholinergic and antioxidant genes have revealed significant association of ACHE rs2571598, BCHE (rs3495), and CAT (rs7943316) with lower levels of their respective enzyme activity. Allelic variants of $C A T$ may exhibit deleterious effect and may result in lower expression of catalase enzyme activity [53], hence implicating it in the risk of toxicity or sensitivity due to chronic OPs exposure.

GSHs are a group of enzymes (GSTP1, GSTT1, and GSTM1) which deactivate free oxygen radicals rendering them unable to interact with other proteins and enzymes having key roles in cellular function [54,55]. Although, there was no significant correlation between GSTP1 (rs1695) genotypes and GSH levels in both OP-exposed subjects of both populations in this study. The results of null variants of GSTT1 in Cameroonian and Pakistani populations appeared also not to be correlated with low levels of GSH. There could perhaps be an adaptive response of erythrocytes to protect themselves 
against damaging oxidative stress and to protect the key biochemical processes and pathways in OP-exposed individuals.

In our study, a multivariate logistic analysis of dominant model of each SNP according to the different biochemical parameters was carried out, in osrder to assess the contribution of these SNPs of interest on toxicological process as well as on other variables such as than BMI andhypertension. We identified that in general, there are relevant overlapping effects, for example, cholinergic enzymes (AChE and BChE) and antioxidant enzymes (catalase, SOD and MDA) were significantly associated with each of the SNPs studied. This association between the SNPs and biochemical variables implies that, in our study populations (Cameroonian and Pakistani) the presence of the mutant allele is positively correlated with considerabe increase in risk of homeostatic dysfunction of these cholinergic and antioxidant enzymes The ACHE SNP rs 2571598 was also positively associated with BMI in Pakistani population. Additionally, the same ACHE SNPs was associated with FRAP levels in Cameroonian population. Although, these gene SNPs have been associated in several other studies with different diseases [55-58], our work, with respect to toxicogenetics, is the first of its kind to link the influence of these five studied SNPs with cholinergic, and oxidative profiles in chronic OP-exposed groups.

\section{Methodology}

\subsection{Study Design and Recruitment of Study Subjects}

This study was cross-sectional and subjects from an intensive agricultural area, making use of heavy pesticides, of Pakistan and Cameroon were recruited to participate in the study. The study participants were recruited from Mora, Figuil, Njobe, and Sa'a in Cameroon and, from Depalpur and Multan in Pakistan. These are cotton growing agriculture areas where organophosphates are mainly applied. Ethical review board of COMSATS University Islamabad, Pakistan (CIIT/BIO/ERB/19/90) and Cameroon National Ethical Committee (\#488/CE/CNERSH) approved the study. The study confirms to tenets of the Helsinki Declaration for human subjects in experiments. All the study subjects were told about the purpose of the study and written consent was obtained before sample collection. The age of study subjects was in the range of 16-60 years, had lived in the OPs sprayed agriculture areas for at least 6 months and exposed to pesticides directly or indirectly.

All the subjects disclosing that he/she has used pesticides other than OPs; people with diabetes, neurological disorders, liver dysfunction, cancer or any other chronic condition; and those whose gas chromatography coupled with high-resolution mass spectrometry (GC-MS) results revealed presence of other pesticide residues than OPs were excluded from the study. Since all the inhabitants in the understudied agriculture areas were directly or indirectly exposed to pesticides, unexposed samples were collected from non-agriculture areas.

Questionnaires were provided to collect demographic characteristics and confounding factors such as age, gender, height, weight, tobacco, work practices, exposure history, use of protective equipments, length of time doing present work activity, and proximity of home to agricultural fields were recorded. The sample size was calculated using the Lorenz formula for a cross-sectional study. According to pancreatic disease prevalence in respective populations $(7.9 \%$ in Pakistan and $7.1 \%$ in sub-Saharan Africa), the minimum size for each site required to have enough statisitcal power (with $10 \%$ increase to keep the power in case of selection bias) was 300 for each country. After screening and exclusion, a total of 637 participants were selected to participate in the study where 200 were exposed and 125 unexposed from Cameroon, and 200 exposed and 112 unexposed from Pakistan.

Sampling method was non-probabilistic. Blood samples were drwan once from all participants using aseptic venipuncture and transported to the lab on ice. The collected blood was divided into two tubes for subsequent analysis for plasma and serum fractions, using EDTA coated and plain glass tubes respectively. The blood was centrifuged at $3500 \mathrm{rpm}$ for $10 \mathrm{~min}$ at $25^{\circ} \mathrm{C}$. Plasma and Serum thus obtained were then stored at $-80^{\circ} \mathrm{C}$ till further analysis. The samples were analyzed at the Institute of 
Medical Research and Medical Plant studies(IMPM)laboratory, Yaounde, Cameroon and Department of Biosciences laboratories at COMSATS University Islamabad, Pakistan.

\subsection{Biochemical Analysis}

\subsubsection{Exposure Measures}

Hernández et al. and Nurulain et al. [7,59] have previously shown that cholinesterase activities particularly $\mathrm{AChE}$ can be used as a marker to measure acute and/or chronic exposure to OPs pesticides. RBC-acetylcholinesterase (RBC-AChE) and butyrylcholinesterase (BChE) activities were determined according to Worek et al. [60] using Specord 50 plus spectrophotometer (Number; 233H1280C, Analytic Jena, Jena, Germany). RBC-AChE was measured from whole blood and plasma was used for BChE. Blood and plasma dilutions were prepared according to the method described by Worek et al. [60]. Spectrophotometric measurements were taken at $436 \mathrm{~nm}\left(\varepsilon=10.6 \times 10^{3} \mathrm{M}^{-1} \mathrm{~cm}^{-1}\right)$ at $37^{\circ} \mathrm{C}$ for $\mathrm{AChE}$ and BChE. For hemoglobin, absorption was noted at $546 \mathrm{~nm}\left(\varepsilon=10.8 \times 10^{3} \mathrm{M}^{-1} \mathrm{~cm}^{-1}\right)$.

To confirm the presence of pesticides in blood, gas chromatography coupled with high-resolution mass spectrometry (GC-MS, System 5975C Agilent, Santa Clara, CA, USA) according to Pérez et al. [61] protocol with minor modifications was employed.

\subsubsection{Measurement of Oxidative Stress Parameters}

Malondialdehyde (MDA) was determined in a colorimetric assay using thiobarbituric acid as described by Wilbur. In fact, carbonyl compounds such as malondialdehyde from lipid oxidation and the breakdown of fatty acid hydroperoxides react with thiobarbituric acid (TBA) to give pink chromophores. The absorbance of that pink chromophores was read at $532 \mathrm{~nm}\left(\varepsilon=1.53 \times 10^{5} \mathrm{M}^{-1} \mathrm{~cm}^{-1}\right)$ and is proportional to the concentration of MDA. The result is expressed in nmol.MDA/mg protein [62].

The reduced glutathione (GSH) was determined using the method previously described by Ellman (1959) with minor modification [63]. The reaction consists of coupling 2,2-dithio-5,5'-dibenzoic acid (DTNB) with thiol (SH) groups of glutathione, to form a colored complex (thionitrobenzoic acid or TNB). TNB at alkaline $\mathrm{pH}(8-9)$ absorbance at $412 \mathrm{~nm}(\varepsilon=13600 / \mathrm{M} \cdot \mathrm{cm}$.) The intensity of the staining was proportional to the concentration of the $\mathrm{SH}$ groups and the result was expressed in $\mathrm{ug} / \mathrm{mL}$.

Measurement of superoxide dismutase (SOD) was done spectrophotometrically according to Misra and Fridovich methods [64]. The auto-oxidation of epinephrine in presence of EDTA is inhibited by SOD at $\mathrm{pH}$ 10.2. The principle of the assay was based on competition between the oxidation reaction of epinephrine $(4.5 \mathrm{mM})$ by superoxide anion $\left(\mathrm{O}_{2}{ }^{-}\right)$. The absorbance of the reaction was read after $30 \mathrm{~s}$ and $150 \mathrm{~s}$ at $480 \mathrm{~nm}$ (4020/M.cm). For activity calculation 1 unit (U) of SOD is that the amount of SOD needed to cause $50 \%$ inhibition of the oxidation of adrenaline to adrenochrome for one min

The ferric reducing ability of plasma (FRAP) as a measure of antioxidant power was measured with Benzie and Strain method with few modifications [65]. The method measuring the ability of serum to reduce iron in an acidic environment ( $\mathrm{pH}$ about 3.6). An intense blue color was formed when ferric tripyridyltriazine complex (TPTZ) was reduced to ferric tripyridyltriazine and absorbance was measured at $593 \mathrm{~nm}$ and the result was expressed in $\mu \mathrm{M}$.

Catalase was measured by evaluating the transformation of dichromate-acetate as described by Boutin et al. [66]. The method is based on the fact that dichromate in acetic acid is reduced to chromic acetate when heated in the presence of $\mathrm{H}_{2} \mathrm{O}_{2}$, with the formation of perchromic acid as an unstable intermediate. The chromic acetate thus produced is measured at $570 \mathrm{~nm}$. Catalase activity was calculated in $\mu \mathrm{mol} / \mathrm{min} / \mathrm{mg}$ protein and was expressed as $\mathrm{U} / \mathrm{mg}$ protein.

Total proteins were measured according to Biuret method: in basic medium, sodium tartrate of sodium and potassium form with cupric ions a soluble complex. Addition of a protein displaces the complex of copper with tartrate to form another copper-protein complex. Absorption was read at $540 \mathrm{~nm}$ and staining intensity was proportional to protein concentration in the medium and expressed in $\mathrm{mg}$ [67]. All the measurements were done using Kenza spectrophotometer (Number; 450 TX, Biolabo, France). 


\subsection{Primer Designing and Chemicals}

Primers designing for the SNPs of selected genes was performed with the Primer 3 version 0.4 .0 (http://bioinfo.ut.ee/primer3-0.4.0/primer3/). NCBI Blast software (https://www.ncbi./Nlm.nih.gov/ tools/primer-blast/) and PCR-in silico using the University of California Santa Cruz (UCSC) genome browser (https://genome.ucsc.edu./cgi-bin/hgpcr) was used to confirm the specificity of the primers All primers were obtained from Macrogen Inc. (Rockville, MD, USA). Primer sequences of all SNPs are given in the Supplementary Data File (Table S1). All the chemicals were obtained from Thermo Fisher Scientific (Waltham, MA, USA) and Sigma-Aldrich (St Louis, MO, USA).

\subsection{Genomic DNA Extraction and SNP Genotyping}

Genomic DNA was extracted by an earlier described method by Lahiri and Nurnberger [68] with slight modifications. Precipitation of DNA was achieved with pure ethanol and stored in TE buffer at $-20^{\circ} \mathrm{C}$ until further use. Genotyping was carried out by PCR-RFLP method and PCR products were incubated at $37^{\circ} \mathrm{C}$ for $14-16 \mathrm{~h}$ with respective restriction enzymes (RE) as follows:

- $\quad$ For SIRT1(rs10823108), RE Hpy188I (Catalog \# ER0761, Thermo Fisher Scientific) cleaves the PCR product into 2 fragments of $261 \mathrm{bp}$ and $134 \mathrm{bp}$ in presence of major A allele while those PCR products having minor $\mathrm{G}$ allele remains intact (band size of $395 \mathrm{bp}$ ).

- $\quad$ For GSTP1 (rs1695), RE BsmAI (Catalog \# ER0761, Thermo Fisher Scientific) cleaves the PCR product into 2 fragments of $201 \mathrm{bp}$ and $148 \mathrm{bp}$ in presence of major G allele while those PCR products having minor A allele remains intact (band size of $349 \mathrm{bp}$ ).

- For CAT (rs7943316), RE MlyI (Catalog \# ER0761, Thermo Fisher Scientific) cleaves the PCR product into 2 fragments of $209 \mathrm{bp}$ and 158bp in presence of major A allele while those PCR products having minor $\mathrm{T}$ allele remains intact (band size of $367 \mathrm{bp}$ ).

- For ACHE (rs2571598), RE Bsu36I (Catalog \# ER0761, Thermo Fisher Scientific) cleaves the PCR product in 2 fragments of $210 \mathrm{bp}$ and $125 \mathrm{bp}$ in presence of major $\mathrm{C}$ allele while those PCR products having minor $\mathrm{T}$ allele remains intact (band size of $335 \mathrm{bp}$ ). RE BanII (Catalog \# ER0761, Thermo Fisher Scientific) cleaves the PCR product into 2 fragments of $209 \mathrm{bp}$ and $126 \mathrm{bp}$ in presence of major $\mathrm{G}$ allele while those PCR products having minor $\mathrm{T}$ allele with band size of 335 bp remains intact.

- $\quad$ For BCHE (rs3495), RE NSP1(XceI) (Thermo Fisher Scientific Catalog\# ER1471). The product bearing A allele at rs3495 gave two fragments of $225 \mathrm{bp}$ and $144 \mathrm{bp}$ length, while the G allele bearing products remain intact and observed band length was $369 \mathrm{bp}$.

- $\quad$ For performed analyses of GSTM1 and GSTT1 genes deletion, we used co-amplification of the gene $\mathrm{HBB}$ as an internal non-OP-exposed.

\subsection{Statistical Analysis}

Stata 15, R 3.2.0, and Graphpad Prism 7.0 (Graphpad Software Inc., La Jolla, CA, USA) softwares were used for statistical analysis of the data. The normality of the distribution of the variables was established using the Shapiro-Wilk test. The $\chi 2$ test was used to verify the agreement of the observed genotype frequencies with those expected according to the Hardy-Weinberg equilibrium. ANOVA test, and post-hoc tests were performed where necessary. A logistical regression model was used to establish a relationship between the explained variables (DM, Genotype) and the explanatory variables (Biochemical Parameters). Odds ratios (ORs) with 95\% confidence intervals (95\% Cis) were calculated. Statistical significance was set at $p \leq 0.05$.

\section{Limitations}

A possible limitation of the present study could be that OPs, although they are used extensively in chosen regions in Pakistan and Cameroon, is the presence of other potential co-influencing factors, such as heavy metals, e.g., arsenic or lead, have not been considered. Another limitation of our work 
is the lack of measurement of certain specific mitochondrial parameters of oxidative stress such as 8-oxoguanine (8-oxoG) or Myeloperoxidase (MPO) that better explain the effect of oxidative stress of DNA damage. For instance, the measurement of 8-oxoG can be very important under OPs exposure condition because the accumulation of 8-oxoG, can cause mitochondrial dysfunction thus, increasing the chance of genetic problems.

\section{Conclusions}

The study concludes that long term exposure of mixture of OPs significantly disbalance the antioxidants in human subjects. The SNPS were associated with investigated oxidative stress parameters and cholinergic enzymes in the population of both groups. the Toxicogenetics screening revealed a substantial association with catalase SNP CAT (rs7943316), GSTP1 (rs1695), and Gene GSTM1 and OPs exposure in both Cameroon and Pakistani groups. Cholinergic enzymes SNPs ACHE (rs2571598), and BCHE (rs3495) also showed a significant association with toxic effects of OPs exposure. Further studies with different ethnic groups and other antioxidant pathway gene SNPs are suggested in order to understand mechanism under pining gene-pesticide interaction and related health outcomes in vulnerable population groups.

Supplementary Materials: The following are available online at http://www.mdpi.com/1422-0067/21/17/6432/s1, Table S1: Primer sequences of study SNPs.

Author Contributions: L.J.M.N. and S.M.N. conceived the study, collected samples, performed experiments, wrote the manuscript, R.H. and N.J.L. supervised genetics part of study, analyzed data and reviewed the manuscript S.R. collected samples, and analyzed, S.B. critically reviewed and provided molecular analysis of data, E.N. and K.K. provided material support and critical review of manuscript. S.M.N., R.H. and K.K. supervised the study. All authors reviewed the final draft. All authors have read and agreed to the published version of the manuscript.

Funding: The authors acknowledge COMSATS University Islamabad, Islamabad Campus and The World Academy of Sciences (TWAS) for providing the opportunity and resources to complete the research work, which is part of Ph.D. dissertation of Mbah Ntepe Leonel Javeres. This project was supported by UHK (VT2019-2021).

Acknowledgments: Authors acknowledge all the participants of the study and Mustajab Ali Eqani, Assistant Professor, Department of Biosciences, COMSATS University Islamabad for facilitating the collection of samples from the area.

Conflicts of Interest: The authors declare no competing interests.

\section{References}

1. Bettiche, F. Contamination of Water by Pesticides under Intensive Production System. 2017. Available online: http://revues.univ-biskra.dz/index.php/cds/article/view/2189 (accessed on 27 October 2019).

2. Suratman, S.; Edwards, J.W.; Babina, K. Organophosphate pesticides exposure among farmworkers: Pathways and risk of adverse health effects. Rev. Environ. Health 2015, 30, 65-79. [PubMed]

3. Li, J.; Ren, F.; Li, Y.; Luo, J.; Pang, G. Chlorpyrifos Induces Metabolic Disruption by Altering Levels of Reproductive Hormones. J. Agric. Food Chem. 2019, 67, 10553-10562. [CrossRef] [PubMed]

4. Mostafalou, S.; Abdollahi, M. Pesticides: An update of human exposure and toxicity. Arch. Toxicol. 2016, 91, 549-599. [CrossRef] [PubMed]

5. Wang-Cahill, F.A. Draft Human Health and Ecological Risk Assessment for Diazinon in Exotic Fruit Fly Applications. Available online: https:/www.aphis.usda.gov/plant_health/ea/downloads/2018/fruit-fly-draftdiazinon-hhera.pdf (accessed on 27 April 2018).

6. Czajka, M.; Matysiak-Kucharek, M.; Jodłowska-Jẹdrych, B.; Sawicki, K.; Fal, B.; Drop, B.; Kruszewski, M.; Kapka-Skrzypczak, L. Organophosphorus pesticides can influence the development of obesity and type 2 diabetes with concomitant metabolic changes. Environ. Res. 2019, 178, 108685. [CrossRef]

7. Nurulain, S.M.; Shafiullah, M.; Yasin, J.; Adem, A.; Al Kaabi, J; Tariq, S.; Adeghate, E.; Ojha, S. Terbufos-sulfone exacerbates cardiac lesions in diabetic rats: A sub-acute toxicity study. Arch. Ind. Hyg. Toxicol. 2016, 67, 126-135. [CrossRef] 
8. Iqbal, A.; Malik, S.; Nurulain, S.M.; Musilek, K.; Kuca, K.; Kalasz, H.; Fatmi, M.Q. Reactivation potency of two novel oximes (K456 and K733) against paraoxon-inhibited acetyl and butyrylcholinesterase: In silico and in vitro models. Chem. Biol. Interact. 2019, 310, 108735. [CrossRef]

9. Nurulain, S.M.; Szegi, P.; Tekes, K.; Naqvi, S.N. Antioxidants in Organophosphorus Compounds Poisoning. Arch. Ind. Hyg. Toxicol. 2013, 64, 169-177. [CrossRef]

10. Miladinović, D.Ć.; Borozan, S.; Ivanović, S. Involvement of cholinesterases in oxidative stress induced by chlorpyrifos in the brain of Japanese quail. Poult. Sci. 2018, 97, 1564-1571. [CrossRef]

11. Kori, R.K.; Hasan, W.; Jain, A.K.; Yadav, R. Cholinesterase inhibition and its association with hematological, biochemical and oxidative stress markers in chronic pesticide exposed agriculture workers. J. Biochem. Mol. Toxicol. 2019, 33, e22367. [CrossRef]

12. Peeples, E.S.; Schopfer, L.M.; Duysen, E.G.; Spaulding, R.; Voelker, T.; Thompson, C.M.; Lockridge, O. Albumin, a New Biomarker of Organophosphorus Toxicant Exposure, Identified by Mass Spectrometry. Toxicol. Sci. 2005, 83, 303-312. [CrossRef]

13. Chang, C.H.; Yu, C.J.; Du, J.C.; Chiou, H.C.; Chen, H.C.; Yang, W.; Chung, M.Y.; Chen, Y.S.; Hwang, B.; Mao, I.F.; et al. The interactions among organophosphate pesticide exposure, oxidative stress, and genetic polymorphisms of dopamine receptor D4 increase the risk of attention deficit/hyperactivity disorder in children. Environ. Res. 2018, 160, 339-346. [CrossRef] [PubMed]

14. Karami-Mohajeri, S.; Ahmadipour, A.; Rahimi, H.R.; Abdollahi, M. Adverse effects of organophosphorus pesticides on the liver: A brief summary of four decades of research. Arhiv Higijenu Rada Toksikol. 2017, 68, 261-275. [CrossRef] [PubMed]

15. Shi, H.; Sui, Y.; Wang, X.; Luo, Y.; Ji, L. Hydroxyl radical production and oxidative damage induced by cadmium and naphthalene in liver of Carassius auratus. Comp. Biochem. Physiol. Part C Toxicol. Pharmacol. 2005, 140, 115-121. [CrossRef] [PubMed]

16. Lukaszewicz-Hussain, A. Role of oxidative stress in organophosphate insecticide toxicity-Short review. Pestic. Biochem. Physiol. 2010, 98, 145-150. [CrossRef]

17. Nanda, M.; Kumar, V.; Fatima, N.; Pruthi, V.; Verma, M.; Chauhan, P.; Vlaskin, M.S.; Grigorenko, A.V. Detoxification mechanism of organophosphorus pesticide via carboxylestrase pathway that triggers de novo TAG biosynthesis in oleaginous microalgae. Aquat. Toxicol. 2019, 209, 49-55. [CrossRef]

18. Park, J.H.; Ko, J.; Park, Y.S.; Park, J.; Hwang, J.; Koh, H.C. Clearance of Damaged Mitochondria Through PINK1 Stabilization by JNK and ERK MAPK Signaling in Chlorpyrifos-Treated Neuroblastoma Cells. Mol. Neurobiol. 2017, 54, 1844-1857. [CrossRef]

19. Dai, H.; Deng, Y.; Zhang, J.; Han, H.; Zhao, M.; Li, Y.; Zhang, C.; Tian, J.; Bing, G.; Zhao, L. PINK1/Parkin-mediated mitophagy alleviates chlorpyrifos-induced apoptosis in SH-SY5Y cells. Toxicology 2015, 334, 72-80. [CrossRef]

20. Das, G.P.; Shaik, A.P.; Jamil, K. Cytotoxicity and Genotoxicity Induced by the Pesticide Profenofos on Cultured Human Peripheral Blood Lymphocytes. Drug Chem. Toxicol. 2006, 29, 313-322.

21. Prakasam, A.; Sethupathy, S.; Lalitha, S. Plasma and RBCs antioxidant status in occupational male pesticide sprayers. Clin. Chim. Acta 2001, 310, 107-112. [CrossRef]

22. Rastogi, S.K.; Satyanarayan, P.V.V.; Ravishankar, D.; Tripathi, S. A study on oxidative stress and antioxidant status of agricultural workers exposed to organophosphorus insecticides during spraying. Indian J. Occup. Environ. Med. 2009, 13, 131-134. [CrossRef]

23. Alves, J.S.; Silva, F.R.; Silva, G.F.; Salvador, M.; Kvitko, K.; Rohr, P.; Santos, C.E.D.; Dias, J.F.; Henriques, J.A.; Silva, J.D. Investigation of potential biomarkers for the early diagnosis of cellular stability after the exposure of agricultural workers to pesticides. Anais Acad. Brasileira Ciências 2016, 88, 349-360. [CrossRef] [PubMed]

24. Ogut, S.; Gultekin, F.; Kisioglu, A.N.; Kucukoner, E. Oxidative stress in the blood of farm workers following intensive pesticide exposure. Toxicol. Ind. Health 2011, 27, 820-825. [CrossRef] [PubMed]

25. Wafa, T.; Nadia, K.; Amel, N.; Ikbal, C.; Insaf, T.; Asma, K.; Hedi, M.A.; Mohamed, H. Oxidative stress, hematological and biochemical alterations in farmers exposed to pesticides. J. Environ. Sci. Health Part B 2013, 48, 1058-1069. [CrossRef] [PubMed]

26. Lu, S.; Liu, S.; Cui, J.; Liu, X.; Zhao, C.; Fan, L.; Yin, S.; Hu, H. Combination of Patulin and Chlorpyrifos Synergistically Induces Hepatotoxicity via Inhibition of Catalase Activity and Generation of Reactive Oxygen Species. J. Agric. Food Chem. 2019, 67, 11474-11480. [CrossRef] 
27. Ahmad, I.; Shukla, S.; Kumar, A.; Singh, C.; Patel, D.K.; Pandey, H.P.; Singh, C. Maneb and paraquat-induced modulation of toxicant responsive genes in the rat liver: Comparison with polymorphonuclear leukocytes. Chem. Biol. Interact. 2010, 188, 566-579. [CrossRef]

28. Hernández, A.F.; López, O.; Pena, G.; Serrano, J.L.; Parrón, T.; Rodrigo, L.; Gil, F.; Pla, A. Implications of Paraoxonase-1 (PON1) Activity and Polymorphisms on Biochemical and Clinical Outcomes in Workers Exposed to Pesticides. In The Paraoxonases: Their Role in Disease Development and Xenobiotic Metabolism; Mackness, B., Mackness, M., Aviram, M., Eds.; Springer: Dordrecht, The Netherlands, 2008; pp. 221-237. Available online: https://doi.org/10.1007/978-1-4020-6561-3_15 (accessed on 29 December 2019).

29. Amir, A.; Haleem, F.; Mahesar, G.; Sattar, R.A.; Qureshi, T.; Syed, J.G.; Khan, M.A. Epidemiological, Poisoning Characteristics and Treatment Outcomes of Patients Admitted to the National Poisoning Control Centre at Karachi, Pakistan: A Six Month Analysis. Cureus 2019, 11, e6229. Available online: https: //www.ncbi.nlm.nih.gov/pmc/articles/PMC6929263/ (accessed on 31 January 2020). [CrossRef]

30. Chuang, C.S.; Yang, K.W.; Yen, C.M.; Lin, C.L.; Lin, C.L. Risk of Seizures in Patients with Organophosphate Poisoning: A Nationwide Population-Based Study. Int. J. Environ. Res. Public Health 2019, 16, 3147. [CrossRef]

31. Kwesiga, B.; Ario, A.R.; Bulage, L.; Harris, J.R.; Zhu, B.P. Fatal cases associated with eating chapatti contaminated with organophosphate in Tororo District, Eastern Uganda, 2015: Case series. BMC Public Health 2019, 19, 767. [CrossRef]

32. Paul, K.C.; Ling, C.; Lee, A.; To, T.M.; Cockburn, M.; Haan, M.; Ritz, B. Cognitive decline, mortality, and organophosphorus exposure in aging Mexican Americans. Environ. Res. 2018, 160, 132-139. [CrossRef]

33. Eyasu, M.; Dida, T.; Worku, Y.; Shafie, M. Acute poisonings during pregnancy and in other non-pregnant women in emergency departments of four government hospitals, Addis Ababa, Ethiopia: 2010-2015. Trop. Med. Int. Health 2017, 22, 1350-1360. [CrossRef]

34. Frawley, J.P.; Fuyat, H.N.; Hagan, E.C.; Blake, J.R.; Fitzhugh, O.G. Marked Potentiation in Mammalian Toxicity from Simultaneous Administration of Twoanticholinesterase Compounds. J. Pharmacol. Exp. Ther. 1957, 121, 96-106. [PubMed]

35. Casida, J.E.; Baron, R.L.; Eto, M.; Engel, J.L. Potentiation and neurotoxicity induced by certain organophosphates. Biochem. Pharmacol. 1963, 12, 73-83. [CrossRef]

36. Muñoz-Quezada, M.T.; Lucero, B.A.; Iglesias, V.P.; Muñoz, M.P.; Cornejo, C.A.; Achu, E.; Baumert, B.; Hanchey, A.; Concha, C.; Brito, A.M.; et al. Chronic exposure to organophosphate (OP) pesticides and neuropsychological functioning in farm workers: A review. Int. J. Occup. Environ. Health 2016, 22, 68-79. [CrossRef] [PubMed]

37. Vidyasagar, J.; Karunakar, N.; Reddy, M.S.; Rajnarayana, K.; Surender, T.; Krishna, D.R. Oxidative stress and antioxidant status in acute organophosphorous insecticide poisoning. Indian J. Pharmacol. 2004, 36, 76-79.

38. Hamza, R.Z.M.M. Hyperglycemic effect of Chlorpyrifos, Profenofos and possible ameliorative role of Propolis and ginseng. Sci. Agric. 2014, 1, 9-14.

39. Jamshidi, H.R.; Ghahremani, M.H.; Ostad, S.N.; Sharifzadeh, M.; Dehpour, A.R.; Abdollahi, M. Effects of diazinon on the activity and gene expression of mitochondrial glutamate dehydrogenase from rat pancreatic Langerhans islets. Pestic. Biochem. Physiol. 2009, 93, 23-27. [CrossRef]

40. Lasram, M.M.; Bouzid, K.; Douib, I.B.; Annabi, A.; El Elj, N.; El Fazaa, S.; Abdelmoula, J.; Gharbi, N. Lipid metabolism disturbances contribute to insulin resistance and decrease insulin sensitivity by malathion exposure in Wistar rat. Drug Chem. Toxicol. 2015, 38, 227-234. [CrossRef]

41. Pourkhalili, N.; Pournourmohammadi, S.; Rahimi, F.; Vosough-Ghanbari, S.; Baeeri, M.; Ostad, S.N.; Abdollahi, M. Comparative Effects of Calcium Channel Blockers, Autonomic Nervous System Blockers, and Free Radical Scavengers on Diazinon-Induced Hyposecretion of Insulin from Isolated Islets of Langerhans in Rats. Arch. Ind. Hyg. Toxicol. 2009, 60, 157-164. [CrossRef]

42. Bautista-Covarrubias, J.; Aguilar-Juárez, M.; Voltolina, D.; Navarro-Nava, R.; Aranda-Morales, S.; Arreola-Hernández, J.; Soto-Jiménez, M.; Frías-Espericueta, M.G. Immunological response of white shrimp (Litopenaeus vannamei) to sublethal concentrations of malathion and endosulfan, and their mixture. Ecotoxicol. Environ. Saf. 2020, 188, 109893. [CrossRef]

43. Ouardi, F.Z.; Anarghou, H.; Malqui, H.; Ouasmi, N.; Chigr, M.; Najimi, M.; Chigr, F. Gestational and Lactational Exposure to Malathion Affects Antioxidant Status and Neurobehavior in Mice Pups and Offspring. J. Mol. Neurosci. 2019, 69, 17-27. [CrossRef] 
44. Aly, N.; El-Gendy, K.; Mahmoud, F.; El-Sebae, A.K. Protective effect of vitamin C against chlorpyrifos oxidative stress in male mice. Pestic. Biochem. Physiol. 2010, 97, 7-12. [CrossRef]

45. Lopez-Sandoval, J.; Sanchez-Enriquez, S.; Rivera-Leon, E.; Bastidas-Ramirez, B.; Garcia-Garcia, M.; Gonzalez-Hita, M. Cardiovascular Risk Factors in Adolescents: Role of Insulin Resistance and Obesity. Acta Endocrinol. Buchar. 2018, 14, 330-337. [CrossRef] [PubMed]

46. Pellegrino, D.; La Russa, D.; Marrone, A. Oxidative Imbalance and Kidney Damage: New Study Perspectives from Animal Models to Hospitalized Patients. Antioxidants 2019, 8, 594. [CrossRef]

47. Sheikhansari, G.; Soltani-Zangbar, M.S.; Pourmoghadam, Z.; Kamrani, A.; Azizi, R.; Aghebati-Maleki, L.; Danaii, S.; Koushaeian, L.; Hojat-Farsangi, M.; Yousefi, M. Oxidative stress, inflammatory settings, and microRNA regulation in the recurrent implantation failure patients with metabolic syndrome. Am. J. Reprod. Immunol. 2019, 82, e13170. [CrossRef] [PubMed]

48. Akhgari, M.; Abdollahi, M.; Kebryaeezadeh, A.; Hosseini, R.; Sabzevari, O. Biochemical evidence for free radicalinduced lipid peroxidation as a mechanism for subchronic toxicity of malathion in blood and liver of rats. Hum. Exp. Toxicol. 2003, 22, 205-211. [CrossRef] [PubMed]

49. Surajudeen, Y.A.; Sheu, R.K.; Ayokulehin, K.M.; Olatunbosun, A.G. Oxidative stress indices in Nigerian pesticide applicators and farmers occupationally exposed to organophosphate pesticides. Int. J. Appl. Basic Med. Res. 2014, 4, S37-S40.

50. Palmirotta, R.; Carella, C.; Silvestris, E.; Cives, M.; Stucci, S.L.; Tucci, M.; Lovero, D.; Silvestris, F. SNPs in predicting clinical efficacy and toxicity of chemotherapy: Walking through the quicksand. Oncotarget 2018, 9, 25355-25382. [CrossRef]

51. Lien, M.Y.; Lin, C.W.; Tsai, H.C.; Chen, Y.T.; Tsai, M.H.; Hua, C.H.; Yang, S.F.; Tang, C. Impact of CCL4 gene polymorphisms and environmental factors on oral cancer development and clinical characteristics. Oncotarget 2017, 8, 31424-31434. [CrossRef]

52. Mikhed, Y.; Görlach, A.; Knaus, U.G.; Daiber, A. Redox regulation of genome stability by effects on gene expression, epigenetic pathways and DNA damage/repair. Redox Boil. 2015, 5, 275-289. [CrossRef]

53. Liu, Y.; Xie, L.; Zhao, J.; Huang, X.; Song, L.; Luo, J.; Ma, L.; Li, S.; Qin, X. Association Between Catalase Gene Polymorphisms and Risk of Chronic Hepatitis B, Hepatitis B Virus-Related Liver Cirrhosis and Hepatocellular Carcinoma in Guangxi Population. Medicine 2015, 94, e702. Available online: https: //www.ncbi.nlm.nih.gov/pmc/articles/PMC4554034/ (accessed on 20 February 2020). [CrossRef]

54. Arévalo-Jaramillo, P.; Idrobo, A.; Salcedo, L.; Cabrera, A.; Vintimilla, A.; Carrión, M.; Bailón-Moscoso, N. Biochemical and genotoxic effects in women exposed to pesticides in Southern Ecuador. Environ. Sci. Pollut. Res. 2019, 26, 24911-24921. [CrossRef] [PubMed]

55. Valeeva, E.T.; Mukhammadiyeva, G.F.; Bakirov, A.B. Polymorphism of Glutathione S-transferase Genes and the Risk of Toxic Liver Damage in Petrochemical Workers. Int. J. Occup. Environ. Med. 2020, 11, 53-58. [CrossRef] [PubMed]

56. Hernández-Guerrero, C.; Parra-Carriedo, A.; Ruiz-De-Santiago, D.; Galicia-Castillo, O.; Buenrostro-Jáuregui, M.; Díaz-Gutiérrez, C. Genetic polymorphisms of antioxidant enzymes CAT and SOD affect the outcome of clinical, biochemical, and anthropometric variables in people with obesity under a dietary intervention. Genes Nutr. 2018, 13, 1. [CrossRef] [PubMed]

57. Scacchi, R.; Ruggeri, M.; Corbo, R.M. Variation of the butyrylcholinesterase (BChE) and acetylcholinesterase (AChE) genes in coronary artery disease. Clin. Chim. Acta 2011, 412, 1341-1344. [CrossRef] [PubMed]

58. Yue, X.G.; Yang, Z.G.; Zhang, Y.; Qin, G.J.; Liu, F. Correlations between SIRT1 gene polymorphisms and diabetic kidney disease. R. Soc. Open Sci. 2018, 5, 171871. [CrossRef] [PubMed]

59. Hernández, A.F.; López, O.; Rodrigo, L.; Gil, F.; Pena, G.; Serrano, J.L.; Parrón, T.; Alvarez, J.C.; Lorente, J.A.; $\mathrm{Pla}, \mathrm{A}$. Changes in erythrocyte enzymes in humans long-term exposed to pesticides: Influence of several markers of individual susceptibility. Toxicol. Lett. 2005, 159, 13-21. [CrossRef]

60. Worek, F.; Mast, U.; Kiderlen, D.; Diepold, C.; Eyer, P. Improved determination of acetylcholinesterase activity in human whole blood. Clin. Chim. Acta 1999, 288, 73-90. [CrossRef]

61. Pérez, J.J.; Williams, M.K.; Weerasekera, G.; Smith, K.; Whyatt, R.M.; Needham, L.L.; Barr, D.B. Measurement of pyrethroid, organophosphorus, and carbamate insecticides in human plasma using isotope dilution gas chromatography-High resolution mass spectrometry. J. Chromatogr. B 2010, 878, 2554-2562. [CrossRef]

62. Wilbur, K.M.; Bernheim, F.; Shapiro, O.W. The thiobarbituric acid reagent as a test for the oxidation of unsaturated fatty acids by various agents. Arch. Biochem. Biophys. 1949, 24, 305-313. 
63. Ellman, G.L. Tissue sulfhydryl groups. Arch. Biochem. Biophys. 1959, 82, 70-77. [CrossRef]

64. Misra, H.P.; Fridovich, I. Superoxide dismutase: "Positive" spectrophotometric assays. Anal. Biochem. 1977, 79, 553-560. [CrossRef]

65. Benzie, I.F.; Strain, J. The Ferric Reducing Ability of Plasma (FRAP) as a Measure of "Antioxidant Power": The FRAP Assay. Anal. Biochem. 1996, 239, 70-76. [CrossRef] [PubMed]

66. Boutin, J.A.; Kass, G.E.; Moldéus, P. Drug-induced hydrogen peroxide production in isolated rat hepatocytes. Toxicology 1989, 54, 129-137. [CrossRef]

67. Gornall, A.G.; Bardawill, C.J.; David, M.M. Determination of serum proteins by means of the biuret reaction. J. Boil. Chem. 1949, 177, 751-766.

68. Lahiri, D.K.; Numberger, J.I. A rapid non-enzymatic method for the preparation of HMW DNA from blood for RFLP studies. Nucleic Acids Res. 1991, 19, 5444. [CrossRef]

(C) 2020 by the authors. Licensee MDPI, Basel, Switzerland. This article is an open access article distributed under the terms and conditions of the Creative Commons Attribution (CC BY) license (http://creativecommons.org/licenses/by/4.0/). 